\title{
Combination of Tangeretin and 5-Fluorouracil Modulates Cell Cycle and Induce Apoptosis on WiDr Cells
}

\author{
Luthfia Indriyani, Adam Hermawan, Riris Istighfari Jenie* \\ Cancer Chemoprevention Research Center, Faculty of Pharmacy, Universitas Gadjah Mada, Yogyakarta \\ http://ccrc.farmasi.ugm.ac.id
}

\begin{abstract}
Co-chemotherapeutics approaches are increasing in cancer treatment in order mainly to suppress the resistence phenomenon of cancer treatment and to enhance the cytotoxic effect of the main chemotherapeutics agent. Tangeretin has been known to have cytotoxic effect to some cancer cells through some pathways in the cells. To explore the potential effect of tangeretin as co-chemotherapeutics agent this research was subjected to study the cytotoxic effect of tangeretin in combination with 5-Fluoro Uracil (5-FU) on WiDr colon cancer cells covering the modulation of cell cycle and apoptosis induction. Cytotoxic effect was examined by using MTT assay while apoptotis induction was determined by annexin-V flowcytometry. Under MTT assay, tangeretin showed weak cytotoxic activity on the cells. However, tangeretin significantly enhanced the cytotoxic effect of 5-FU on the cells. This cochemotherapeutics effect likely correlated with cell cycle modulation effect, especially in inducing polyploidy phenomenon as expressed in the flowcytometric graph of the DNA content. This combination also increased apoptosis induction. These result suggest that tangeretin is potential to be developed as co-chemotherapeutic agent for 5-Fu on colon cancer and further molecular mechanism need to be explored.
\end{abstract}

Keywords: Tangeretin, 5-Fluorourasil, WiDr, cell cycle, apoptosis.

\section{INTRODUCTION}

Colon cancer has $3^{\text {rd }}$ highest incidence in United States. It is estimated about 106,100 new cases and 49,200 death cases of colon cancer occurred in 2009 (Jemal, et al., 2009). One of first line therapy against colon cancer is 5-Fluorouracl (5-Fu). Nevertheless, 5-Fu gave effectivity below $15 \%$ on colon cancer patient (Yoshikawa, et al., 2001). This phenomenon is expected due to chemoresistance caused by thymidilate synthetase overexpression (Giovannetti, et al., 2007). Thus, efforts are developed to overcome this phenomenon. Usually, 5-Fu is combined with other chemotherapeutic agents such as leucovorin (Zhang, et al., 1992), irinotecan, or oxaliplatin (Meyerhardt and Mayer, 2005). But, combination chemotherapy with other chemotherapeutic agent causes higher cost and adverse effect (Meyerhardt and Mayer, 2005).

Tangeretin is polymethoxy flavon found in citrus peels. Tangeretin possesses antiproliferative activity, induce apoptosis, and cause cell cycle arrest against some cancer cells (Choi, et al., 2007; Pan, et al., 2002). This compound performed cytotoxic activity with $\mathrm{IC}_{50}$ less than $5 \mu \mathrm{M}$ on melanoma cells (Yanez, et al., 2004), lung cancer, colon cancer, breast cancer, and prostate cancer cells (Manthey and Guthrie, 2002). Pan, et al. (2002) reported that tangeretin inhibits COLO 205 colon cancer cells through inhibiting $\mathrm{Rb}$ phosphorylation and CDK2/4 inhibition mediated G1 arrest. Those researches exhibits potency of tangeretin as chemoprevention agent.

The aim of this study is to evaluate cytotoxicity, apoptosis induction, and cell cycle modulation of tangeretin combined with 5-Fu on Widr colon cancer cells.

*Corresponding author e-mail: ririsjenie@gmail.com 


\section{MATERIALS AND METHODS}

\section{Materials}

Citrus flavonoid tangeretin were from Sigma (Cat no T8951-5MG). Chemotherapeutic agent 5-Fluorouracil "Ebewe" 250mg/ml were from P.T. Ferron Par Pharmaceutical (Cikarang, Indonesia). Sample were dissolved in DMSO (DMSO 99,5\% pro GC, Sigma Aldrich, Germany) as co-solven, and dilluted 1:50 with $20 \mathrm{mg} / \mathrm{ml}$ of Bovine Serum Albumin (BSA) in PBS.

\section{Cell Culture}

Widr colon cancer cells was obtained from the collection of Laboratory of Parasitology, Faculty of Medicine, Universitas Gadjah Mada (UGM). Cells were grown in medium RPMI 1640 (Gibco, USA) containing fetal bovine serum (FBS) $10 \% \quad(\mathrm{v} / \mathrm{v}) \quad(\mathrm{FBS}$ qualified, Gibco, USA), and penicillinstreptomisin $1 \%(\mathrm{v} / \mathrm{v})$ (Gibco, USA). Cells were harvested using trypsin-EDTA $0,025 \%$ (Gibco, Canada).

\section{Cytotoxic Assay}

Cytotoxic assay was done using MTT [34, 5-dimetiltiazol-2-yl)-2,5 difeniltetrazolium bromide] (Mosmann, 1983). Cells in 80\% confluent were harvested and counted, then diluted with complete culture medium. The cells then were transferred into a 96-well plate with a total of $5 \times 10^{3}$ cells/well followed by 48 hours incubation. After that, the sample was added to the wells at various concentrations with cosolvent DMSO and incubated at $37^{\circ} \mathrm{C}$ in a $5 \%$ $\mathrm{CO}_{2}$ incubator for 24 hours. At the ends of incubation, $100 \mu \mathrm{L}$ MTT reagent with concentration $0.5 \mathrm{mg} / \mathrm{ml}$ in DMEM was added into each well. The plate then incubated at $37^{\circ} \mathrm{C}$ for 3 hours until formazan was formed. If formazan was formed, stopper SDS $10 \%$ in $0.01 \mathrm{~N} \mathrm{HCl}$ was added. Plate then was wrapped with paper or alumunium foil and incubated in dark condition overnight. Absorbance was determined with an ELISA reader at $\lambda 595 \mathrm{~nm}$.

\section{Cell Cycle and Apoptosis Analysis}

WiDr cells were seeded at $5 \times 10^{5}$ cells/well on six wells tissue culture plate. After 24 hours incubation cells were treated with tangeretin alone and its combination with $5-\mathrm{Fu}$. After $24 \mathrm{~h}$ of these treatments, cells were trypsinized and cells pellets were collected. Cells were trypsinized, spin at $2000 \mathrm{rpm}$ for 30 seconds and washed twice with cold PBS. Cells were resuspended in propidium iodide solution $(50 \mu \mathrm{g} / \mathrm{mL}$ in PBS contained $1 \%$ triton X-100) and then treated with RNAse DNAse free (20 $\mu \mathrm{g} / \mathrm{mL}$ ) for 10 minutes at $37^{\circ} \mathrm{C}$. The treated cells then subjected to FACS flowcytometry and data was analyzed by using ModFit LT 3.0 program.

\section{RESULTS AND DISCUSSION}

\section{Cytotoxic Effect of Tangeretin and 5-Fu on WiDr Cells}

In this study, both tangeretin and $5-\mathrm{Fu}$ didn't inhibit over $50 \%$ of WiDr cells, thus $\mathrm{IC}_{50}$ value couldn't be obtained (Fig. 1A). However, tangeretin and 5-Fu treatment altered membrane permeability so that boundary between cells wasn't clear. Treated cells also became more rounded (Fig.1B).

\section{Combination Effect of Tangeretin and 5- Fu on WiDr Cells}

Combinational cytotoxic assay was done by combined $5-\mathrm{Fu}(1150$ and $2300 \mu \mathrm{M})$ with tangeretin $(10$, 50, dan $100 \mu \mathrm{M})$. Tangeretin increased cytotoxic effect of 5-Fu significantly on WiDr cells compared to 5-Fu treatment alone $(p<0.05)$ (Fig.2). However, WiDr cells viability remained high $(>70 \%)$, indicating those combination need to be optimized. 


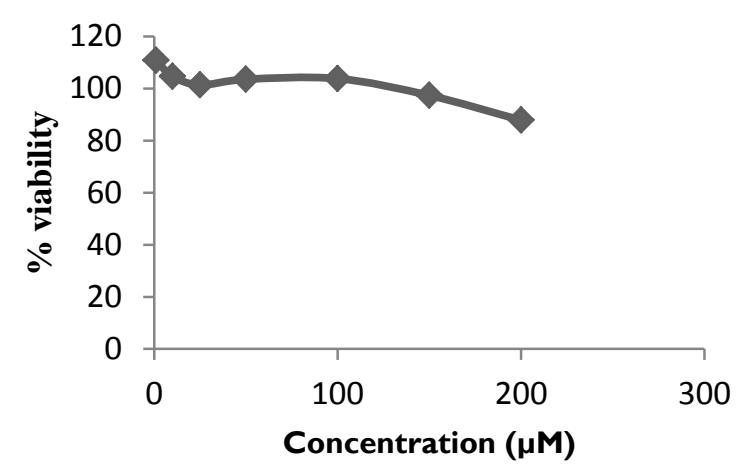

(A)

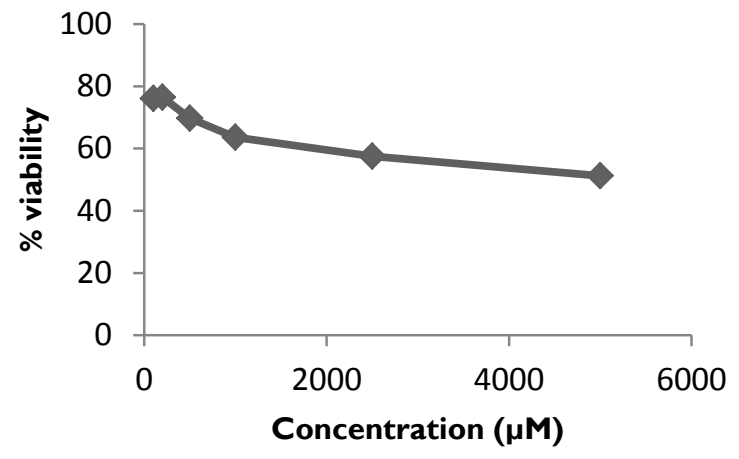

(B)

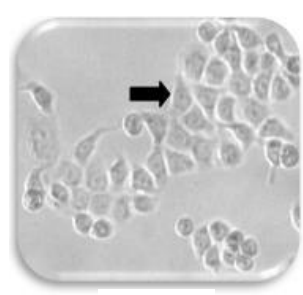

(C)

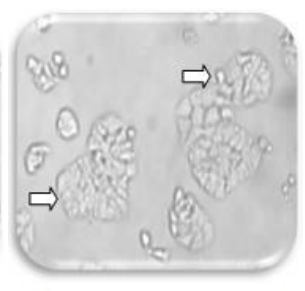

(D)

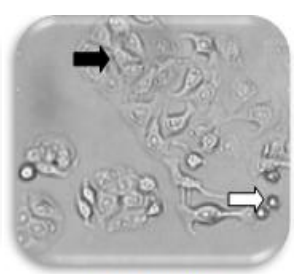

(E)

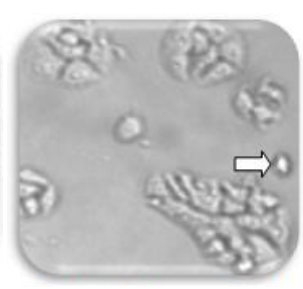

(F)

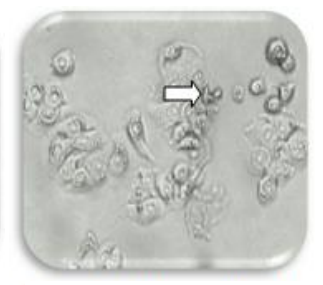

(G)

Figure I. Cytotoxic Effect of tangeretin and 5-Fu on WiDr Cells. WiDr cells (5000 cells/well) were seeded in 96 wellplate and incubated for $\mathbf{4 8 h}$. Cell viability was determined by using MTT assay as described in methods. Graph between concentration and cells viability of (A) Tangeretin and (B) 5-Fu (B) showed low cytotoxic activity on WiDr cells. Nevertheless, treatment with both compounds altered cells morphology. Cells treated with (C) none, (D) tangeretin $50 \mu \mathrm{M}$, (E) 5-Fu I I $50 \mu \mathrm{M}$, (F) 5-Fu II $50 \mu \mathrm{M}$ and tangeretin $50 \mu \mathrm{M}$, and (G) 5-Fu $2300 \mu \mathrm{M}$ and tangeretin $100 \mu \mathrm{M}$. Black arrows $(\Rightarrow)$ showed viable cells while white arrows $(\Rightarrow)$ ) showed alteration of cells morphology. Cells were observed under light microscope with 100x magnifications.

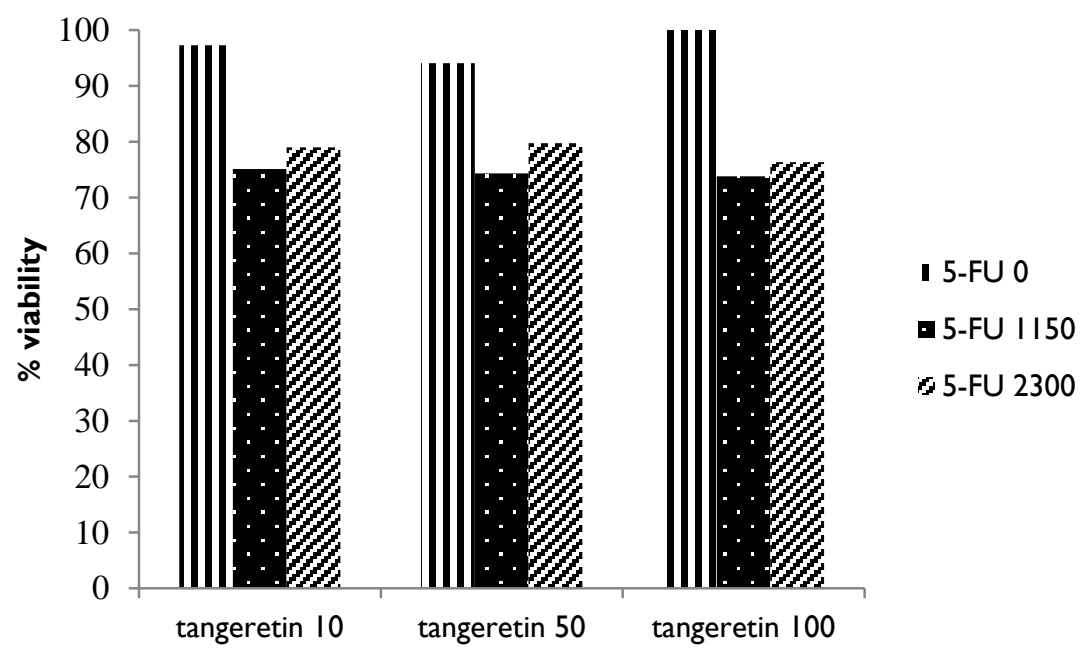

Figure 2. Combination Cytotoxic Effect of tangeretin and 5-Fu on WiDr Cells. WiDr cells (5000 cells/well) were seeded in 96 wellplate and treated with tangeretin 10,50 , and $100 \mu \mathrm{M}$ in combination with 5-Fu 1150 and $2300 \mu \mathrm{M}$, then incubated for 48h. Cells viability was determined by using MTT assay as described in methods. Tangeretin decreased cells viability compared to single 5-Fu treatment. Data were mean of 3 replications and analyzed using One way ANOVA. 


\section{Effect of Tangeretin and 5-Fu on Cell Cycle and Apoptosis}

Treatment with $5-\mathrm{Fu}$ or tangeretin solely induced cells accumulation of the cells in subG1 phase and decreased cells in other phases. This phenomenon seems contrary with the cytotoxic result that showed no effect in decreasing cell viability. This contrary result may due to some debris following the assay, but, some debris could be representing some apoptotic evidence. Moreover, combination of them caused extensive cells accumulation in subG1 phase (73.12\%) (Fig.3 and Table I), that may be representing some apoptotic cells. Thus, 5-Fu, tangeretin, and combination of those compounds likely induced apoptosis extensively compared to untreated cells.
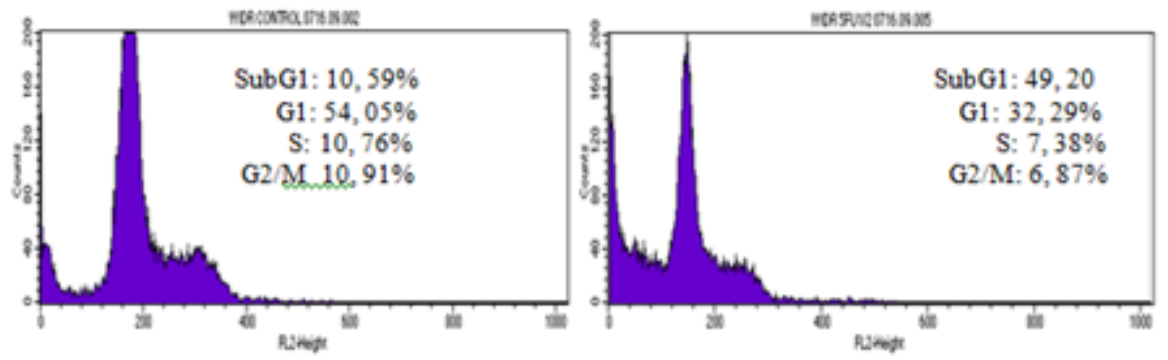

(Control)

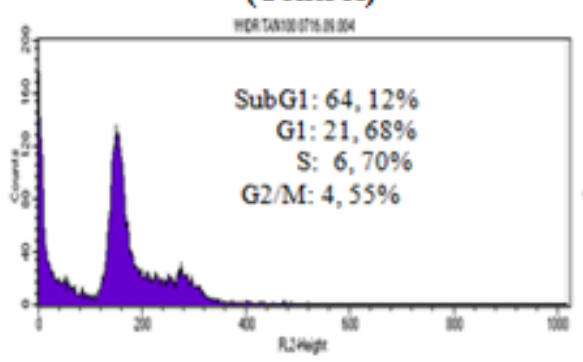

(5-FU $2300 \mu \mathrm{M})$

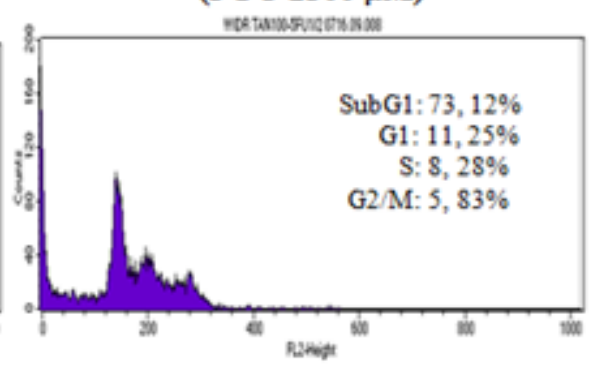

(Tangeretin $100 \mu \mathrm{M}$ )

(5-FU $2300 \mu \mathrm{M}+$ tangeretin $100 \mu \mathrm{M})$

Figure 3. Effect of Tangeretin and 5-Fu on Cell Cycle and Apoptosis. WiDr cells were treated with 5Fu and tangeretin then incubated for $\mathbf{2 4}$ hours. Cells then were harvested and prepared for flowcytometric analysis using PI as described in methods. Figures are distribution profiles of the cells treated with (A) none, (B) 5-Fu $2300 \mu \mathrm{M}$, (C) tangeretin $100 \mu \mathrm{M}$, (D) 5-Fu 2300 $\mu \mathrm{M}$ and tangeretin $100 \mu \mathrm{M}$.

Table I. Distribution of WiDr cells (\%) after treatment with tangeretin and 5-Fu

\begin{tabular}{lcccc}
\hline \multicolumn{1}{c}{ Treatment } & \multicolumn{3}{c}{ Phase } \\
\cline { 2 - 5 } & Sub G I & G I & S & G2/M \\
\hline None $($ control) & 10,59 & 54,05 & 10,76 & 10,91 \\
5-FU 2300 $\mu \mathrm{M}$ & 49,20 & 32,29 & 7,38 & 6,87 \\
Tangeretin I00 $\mu \mathrm{M}$ & 64,12 & 21,68 & 6,70 & 4,55 \\
Tangeretin $100 \mu \mathrm{M}$ and 5-FU $2300 \mu \mathrm{M}$ & 73,12 & 11,25 & 8,28 & 5,83 \\
\hline
\end{tabular}

This study exhibited low cytotoxic activity of tangeretin and the $\mathrm{IC}_{50}$ of tangeretin could not be obtained. Based on previous study, tangeretin targets p53 in cancer cells, while WiDr as the model in this study showed p53 mutation (Noguchi, et al., 1979). This result probably caused low efficacy of tangeretin on WiDr cells. Beside, 5-Fu also showed low efficacy that may be due to WiDr cells resistance through PI3K/Akt activation (Benistan, et al., 2000).
Due to low efficacy of tangeretin solely, combination cytotoxic assay was done. Tangeretin increased 5-Fu cytotoxicity on WiDr cells. Furthermore, combination of tangeretin and 5-Fu likely caused excessive apoptosis. This can be effect of tangeretin to interfere PI3K/Akt pathway. Tangeretin also downregulated downstream of PI3K/Akt pathway, such as NF-kB (Arafa, et al., 2009). Downregulation of NF- $\mathrm{KB}$ leads to decrease of anti-apoptotic protein, such as Bcl-2, IAPs, and $\mathrm{Bcl}-\mathrm{xl}$. Other mechanism interfere by tangeretin 
is p21 independent p53 expression, that may contribute in the apoptosis induction.

All of the data in this study showed that tangeretin improved the cytotoxic effect of 5-FU on WiDR cells through apoptosis induction and cell cycle modulation. These results supported tangeretin to be developed as co-chemotherapeutic agent, especially to cure colon cancer that resistant to 5-FU. However, in order to lead for the application more precisely, the data should be more completed by exploring the specific targets of the agent as well as its effect in the in vivo experiment.

\section{ACKNOWLEDGEMENT}

We thanks to the Faculty of Pharmacy Universitas Gadjah Mada UGM) who give the funding for this research through Hibah Madya Fakultas Farmasi UGM 2009.

\section{REFERENCES}

Arafa, el-S.A., Zhu, Q., Barakat, B.M., Wani, G., Zhao, Q., El-Mahdy, M.A. and Wani, A.A., 2009, Tangeretin sensitizes cisplatin-resistant human ovarian cancer cells through downregulation of phosphoinositide 3kinase/Akt signaling pathway, Cancer Res., 69(23), 8910-8917.

Bénistant, C., Chapuis, H., Roche, S., 2000, A specific function for phosphatidylinositol 3-kinase alpha (p85alpha-pllOalpha) in cell survival and for phosphatidylinositol 3-kinase beta (p85alpha-pllobeta) in de novo DNA synthesis of human colon carcinoma cells, Oncogene., 19(44), 5083-5090.

Choi, S., Ko, H., Ko, S., Hwang, J., Park, J., Kang, S., Han, S., Yun, S. and Kim, S., 2007, Correlation between Flavonoid Content and the NO Production Inhibitory Activity of Peel Extracts from Various Citrus Fruits, Biol. Pharm. Bull., 30(4), 772-778.

Giovannetti, E., Backus, H.H.J., Wouters, D., Ferreira, C.G., van Houten, V.M.M., Brakenhoff, R.H., Poupon, M-F., Azzarello, A., Pinedo, H.M. and Peters, G.J., 2007, Changes in the status of p53 affect drug sensitivity to thymidylate synthase (TS) inhibitors by altering TS levels, British J. Can., 96, 769-775.

Jemal, A., Siegel, R., Ward, E., Hao, Y., Xu, J. and Thun, M.J., 2009, Cancer Statistics 2009, C.A. Cancer J. Clin., 59, 225-249.

Liu, H.C., Chen, G.G., Vlantis, A.C., Leung, B.C.S., Tong, M.C.E. and van Hasselt, C.A., 2006, 5-Fluorouracil Mediates Apoptosis and GI/S Arrest in Laryngeal Squamous Cell Carcinoma via a p53-Independent Pathway, The Cancer I., I 2(6), 482-493.

Manthey, J.A. and Guthrie, N., 2002, Antiproliferative Activities of Citrus Flavonoids against Six Human Cancer Cell Lines, J. Agric. Food Chem., 50, 5837-5843.

Meyerhardt, J.A. and Mayer, R.J., 2005, Systemic therapy for colorectal cancer, N. Engl. J. Med., 352(5), 476-487.

Nogata, Y., Sakamoto, K., Shiratsuchi, H., Ishii, T., Yano, M., and Ohta, H., 2006, 'Flavonoid composition of Tissues of Citrus species', Biosci. Biotechnol. Biochem., 70, 178-192

Noguchi, P., Wallace, R., Johnson, J., Early, E.M., O'Brien, S. and Ferrone, S., 1979, Characterization of the WiDr: a Human Colon Carcinoma Cell Line, In Vitro, I 5(6), 40I-408.

Pan, M.H., Chen, W.J., Shiau, S.Y.L., Ho, C.T., and Lin, J.K., 2002, Tangeretin Induces Cell-cycle GI Arrest Through Inhibiting Cyclin-dependent Kinases 2 and 4 Activities As Well As Elevating Cdk Inhibitors p2I and p27 in Human Colorectal Carcinoma Cells, Carcinogenesis, 23(10), 1677-1684.

Yanez, J., Vicente, V., Miguel, A., Julián Castillo, Obdulio Benavente-García, Manuel Canteras, and José A. Lozano Teruel, 2004, Cytotoxicity and Antiproliferative Activities of Several Phenolic Compounds Against Three Melanocytes Cell Lines: Relationship Between Structure and Activity, Nutrition And Cancer, 49(2), I9I-199

Yoshikawa, R., Kusunoki M., Yanagi H., Noda M., Furuyama Jl., Yamamura T. and Hashimoto-Tamaoki T., 200I, Dual antitumor effects of 5-fluorouracil on the cell cycle in colorectal carcinoma cells: a novel target mechanism concept for pharmacokinetic 
modulating chemotherapy, Cancer Res,

$$
\text { 6I, 1029-1037 }
$$

Zhang, Z.G., Harstrick, A. and Rustum, Y.M., 1992, Modulation of fluoropyrimidines: role of dose and schedule of leucovorin administration. Semin Oncol., 19 (3), 10-5. (abst.) 